\title{
Oocyte development in bovine primordial follicles is promoted by activin and FSH within a two-step serum-free culture system
}

\author{
Marie McLaughlin and Evelyn E Telfer \\ Centre for Integrative Physiology, University of Edinburgh, Hugh Robson Building, George Square, \\ Edinburgh EH8 9XD, UK \\ Correspondence should be addressed to E E Telfer; Email: evelyn.telfer@ed.ac.uk
}

\begin{abstract}
Quiescent follicles of large mammals initiate growth within cultured pieces of ovarian cortex. Systems capable of sustaining in vitro development from this early stage until oocyte maturation would allow investigation of mechanisms regulating oocyte development in its entirety. The aims of this study were 1) to determine whether bovine follicles initiated to grow in vitro could be isolated from the cortical environment, and could undergo further development and 2) to evaluate the effect of activin and FSH on the development of secondary follicles derived from primordial follicles. Fragments of bovine ovarian cortex were cultured in serum-free medium for 6 days; thereafter, secondary follicles were isolated for further culture. After a maximum total of 21 days in vitro, follicles were either processed for histological assessment or opened to release the oocyte-cumulus complexes for inspection by light microscopy. Compared with control, significant follicle and oocyte growth were observed in activin-exposed follicles, with or without FSH, with some oocyte diameters measuring over 100 microns following a total in vitro period of 15 days. Significant oestradiol secretion was observed in follicles cultured in activin alone after a total of 9 days in vitro compared with other treatment groups; however, this effect was not sustained. In summary, this study demonstrates the promotion of primordial bovine follicle development within a two-step serum-free culture system with oocyte diameters $>100 \mu \mathrm{m}$ achieved over 15 days in vitro. Further development of this system is needed to support complete oocyte growth and thereafter in vitro maturation.

Reproduction (2010) 139 971-978
\end{abstract}

\section{Introduction}

Current understanding of the mechanisms underpinning oocyte development in immature follicles is incomplete. The ability to support the development of primordial bovine follicles through to acquisition of oocyte competency in vitro would not only advance the understanding of germ cell development in non-rodent species, but could also provide mature oocytes for assisted reproductive technologies in species understood to require a prolonged follicular growth period.

The mammalian follicle reserve mainly comprises primordial follicles (Gosden \& Telfer 1987), which also represent the population of follicles least affected by apoptotic sequelae (Telfer 1998, Telfer et al. 1998), making them promising candidates for in vitro growth and subsequent oocyte harvesting. Individual culture of primordial follicles is technically demanding (Abir et al. 1997, Oktay et al. 1997); however, initiation of growth and early development in vitro have been achieved in human (Hovatta et al. 1997, 1999, Wright et al. 1999, Telfer et al. 2008) and large animal (Wandji et al. 1996, 1997, Braw-Tal \& Yossefi 1997, Yang \& Fortune 2006, 2007) follicles within small pieces of ovarian cortex. Previous studies using primate and bovine models have demonstrated a reduction in the primordial population and a corresponding increase in the growing follicle population within gonadotrophin-free cultures of ovarian cortex with activated follicles reaching the secondary stage of development (Wandji et al. 1996, 1997, Braw-Tal \& Yossefi 1997, Gigli et al. 2006, Yang \& Fortune 2006, 2007). In vitro growth of follicles within cortical pieces can be successfully supported for extended periods of time (Hovatta et al. 1997, Louhio et al. 2000, Zhang et al. 2004, Segino et al. 2005, Fabbri et al. 2007); however, it is recognised that to achieve advanced development, follicles require to be released from the presumed inhibitory stromal environment (Abir et al. 1997, Telfer et al. 2008).

Multi-step systems have already been designed to support in vitro follicle development in mice with the birth of pups from in vitro matured oocytes derived from cumulus-oocyte complexes (Eppig \& Schroeder 1989), and primordial (Eppig \& O'Brien 1996) and primary follicles (Spears et al. 1994); however, to date, it has not been possible to repeat this success in large mammals using oocytes from such immature follicles. A major obstacle to progress in large species is oocyte degeneration associated with loss of oocyte and somatic 
cell contact particularly over a prolonged culture period; therefore, it is imperative that an understanding of the impact of culture conditions on the maintenance of intercellular associations is realised.

In the following experiment, a two-step culture system was designed to promote the activation of follicle growth within fragments of ovarian cortex followed by isolation and individual culture of secondary follicles. The transforming growth factor- $\beta$ superfamily member activin, previously associated with the maintenance of oocyte-somatic cell adhesion and a recognised promoter of preantral follicle development (Hulshof et al. 1997, Liu et al. 1998, Zhao et al. 2001, Thomas et al. 2003, Silva et al. 2006, Telfer et al. 2008), and FSH were chosen as culture medium supplements. Activation and early follicle growth occur in the absence of gonadotrophins (Peters et al. 1973, McNatty et al. 1990). Development beyond the early antral stage is critically dependent on the presence of FSH (Oktay et al. 1998); however, the precise effect of FSH on preantral follicle development is unclear. It has been demonstrated that FSH can augment the action of activin, which in turn simulates $\mathrm{FSH}$ receptor expression in cultured murine granulosa cells (Xiao et al. 1992), confirming a relationship between the follicular actions of FSH and activin. In this experiment, the effect of activin and activin in combination with FSH on the development of secondary bovine follicles grown in vitro was assessed with regard to follicle and oocyte growth, steroidogenesis and maintenance of normal oocyte morphology.

\section{Results}

\section{Follicle growth and differentiation}

To confirm the developmental stage of follicles in fresh tissue, a total of 12 fragments were randomly selected prior to culture, fixed in Bouin's solutions and processed as described for histological assessment. The mean distribution of follicles in freshly fixed tissue (day 0 ) was compared to that of ten fragments cultured for 6 days. Follicles were categorised by a modification of the system used by Wandji et al. (1996) as follows: 1) quiescent follicles: oocytes surrounded by a complete or incomplete single layer of cells, either all flattened (primordial) or a mixed layer of flattened and cuboidal cells (transitory), 2) primary follicles: follicles comprising an oocyte surrounded by a single complete layer of cuboidal granulosa cells, and 3) secondary follicles: multilaminar follicles with more than a complete single layer of granulosa cells. Follicle survival was high in cultured tissue fragments, with $<10 \%$ follicle degeneration observed in any of the treatment groups. As shown in Fig. $1 \mathrm{i}$, a significantly greater percentage $(P<0.01)$ of growing follicles (primary) and a corresponding significant decrease in the percentage of quiescent follicles $(P<0.01)$ were observed in cultured fragments compared with freshly fixed tissue, which contained predominantly quiescent follicles (Fig. 1ii). Secondary follicles (mean diameter $111 \pm 1.46 \mu \mathrm{m}$ ) were dissected from cultured cortical strips (Fig. 1iii and iv), and grown for 6 days in control medium $(n=31)$ or in medium supplemented with $100 \mathrm{ng} / \mathrm{ml}$ recombinant human activin A (rhAct A) alone $(n=70)$ or $100 \mathrm{ng} / \mathrm{ml}$ rhAct A in combination with $50 \mathrm{ng} / \mathrm{ml}$ recombinant human FSH (rhFSH; $n=57)$. Significant growth occurred in follicles supplemented with $100 \mathrm{ng} / \mathrm{ml}$ rhAct $A$ in the presence $(P<0.01)$ or absence $(P<0.01)$ of $50 \mathrm{ng} / \mathrm{ml} \mathrm{rhFSH}$ compared with control over a 12-day in vitro period. Activin-exposed follicles were cultured for a maximum of 21 days; due to poorer growth rates, control follicles were not cultured beyond 12 days. Follicle growth increased significantly at days 15 and 18 in the presence of $100 \mathrm{ng} / \mathrm{ml}$ rhAct $A$ and $50 \mathrm{ng} / \mathrm{ml} \mathrm{rhFSH}$ compared with activin alone $(P<0.05)$; however, by day 21 of the
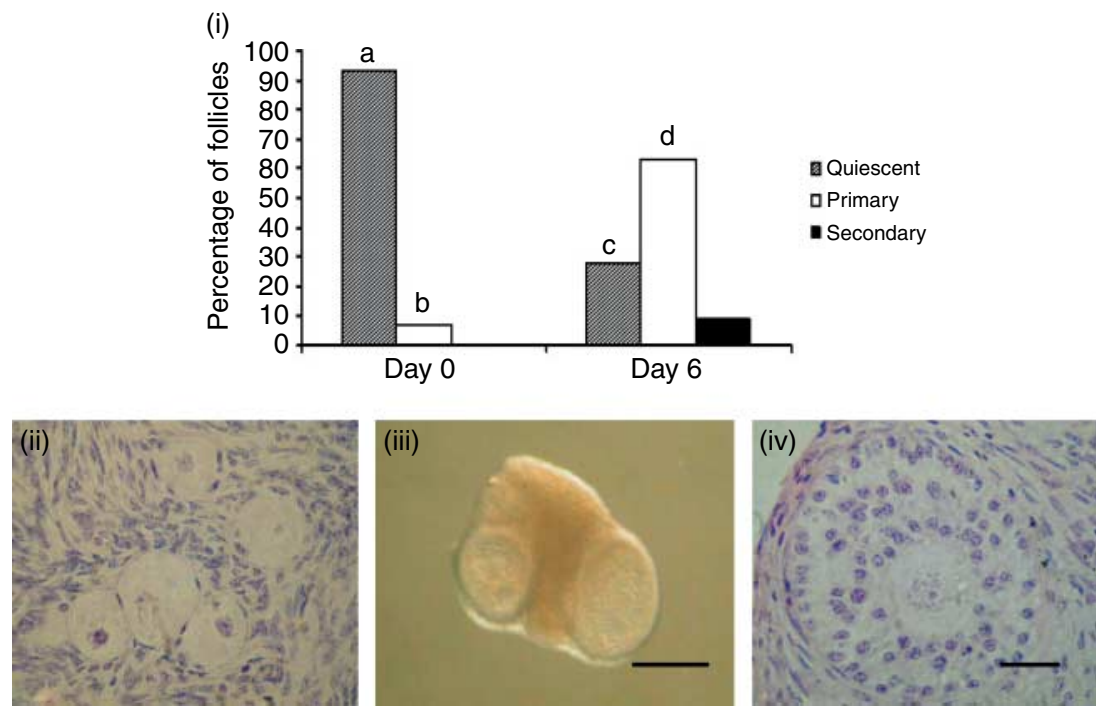

Figure 1 Effect of culture on the quiescent and growing follicle population in bovine cortical fragments. (i) a, b, c and d indicate differences between quiescent and primary follicle populations. A significant decrease $(P<0.01)$ in the percentage of quiescent follicles was observed after 6 days in culture with a corresponding increase in the percentage of primary follicles $(P<0.01)$. No secondary follicles were observed in freshly fixed (day 0) tissue which contained predominately quiescent follicles (ii). Secondary follicles were dissected from strips of bovine cortex following 6 days in vitro (iii), bar $=100 \mu \mathrm{m}$ and (iv), bar $=25 \mu \mathrm{m}$. 

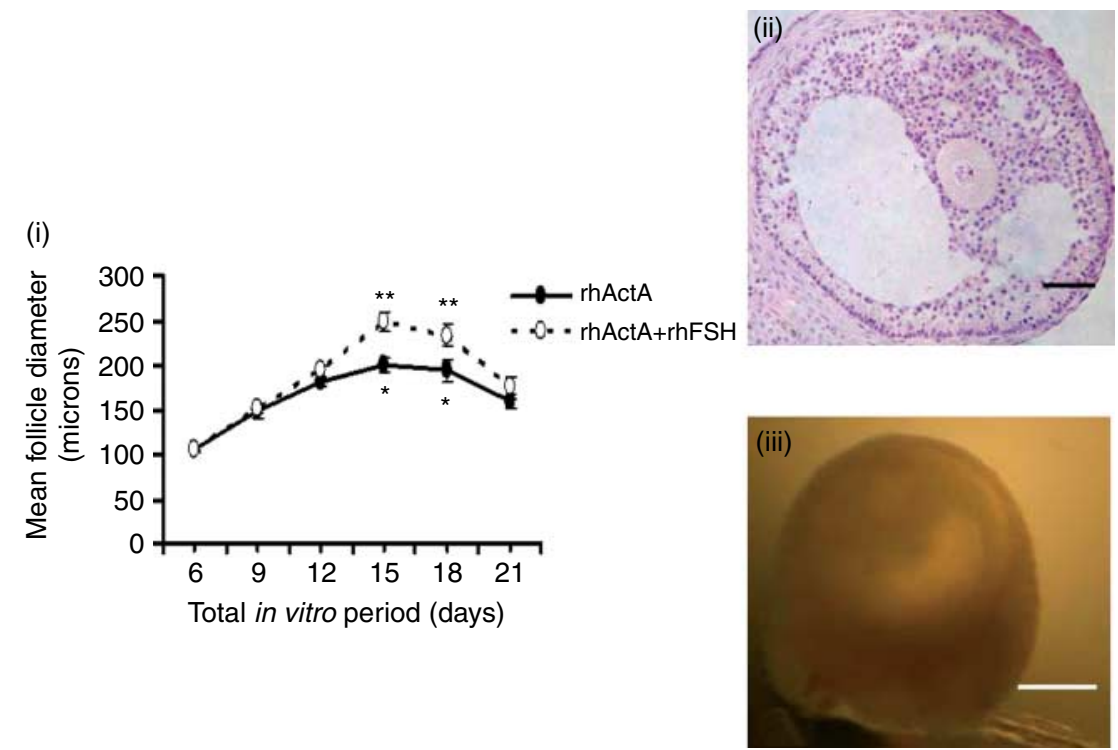

Figure 2 Effect of rhAct A and FSH on follicle development over 21 days in vitro. (i) Values are mean follicle diameters \pm S.E.M. ${ }^{*}$ and ${ }^{* *}$ indicate significant differences betweens treatments. Mean follicle diameters were greater in the presence of $100 \mathrm{ng} / \mathrm{ml} \mathrm{rhAct} \mathrm{A} \mathrm{and} 50 \mathrm{ng} / \mathrm{ml} \mathrm{FSH}$ (open circles) on days $15(P<0.05)$ and 18 $(P<0.05)$ compared with $100 \mathrm{ng} / \mathrm{ml}$ rhAct A alone (closed circles). Follicles cultured in control medium for a total of 12 days were significantly smaller than those cultured in the presence of activin over the same time period (not shown). (ii) Antral cavity formation in a follicle cultured in the presence of $100 \mathrm{ng} / \mathrm{ml}$ rhAct $A$ and $50 \mathrm{ng} / \mathrm{ml}$ FSH for 15 days; bar $=50 \mu \mathrm{m}$. (iii) Formation of antra could occasionally be seen during the in vitro period; bar $=100 \mu \mathrm{m}$. in vitro period, mean follicle diameters in both groups had declined sharply (Fig. 2i). The presence of an antrum was determined on histological inspection (Fig. 2ii), though occasionally cavity formation could be seen by light microscopy during the in vitro period (Fig. 2iii). Significant antral formation was observed in follicles cultured in $100 \mathrm{ng} / \mathrm{ml}$ rhAct A alone $(P<0.05)$ or $100 \mathrm{ng} /$ $\mathrm{ml}$ rhAct $\mathrm{A}$ and $50 \mathrm{ng} / \mathrm{ml}$ rhFSH $(P<0.05)$ compared with follicles cultured in control, with approximately a third of the follicles in both activin-exposed groups forming cavities.

\section{Oocyte growth and cumulus complex morphology}

Follicles grown in vitro were isolated and cultured for up to 21 days in the presence or absence of $100 \mathrm{ng} / \mathrm{ml}$ rhAct $A$, or in the presence of $100 \mathrm{ng} / \mathrm{ml}$ rhAct $A$ in combination with $50 \mathrm{ng} / \mathrm{ml}$ rhFSH. As shown in Fig. 3i, significant oocyte growth occurred over 12 days in isolated secondary follicles cultured in the presence of $100 \mathrm{ng} / \mathrm{ml}$ rhAct A with or without $50 \mathrm{ng} / \mathrm{ml} \mathrm{rhFSH}$ compared with oocytes within cortical fragments cultured for 6 days only $(P<0.01)$ and isolated secondary follicles cultured in control medium $(P<0.05)$. The normality of oocyte morphology was assessed by determining the general circularity of the oocyte and the integrity of the oolemma and zona pellucida, and the presence of a germinal vesicle and nucleolus in each section was evaluated as illustrated in Fig. 3ii and iii. Therefore, grossly spherical oocytes with an intact oolemma, distinguishable zona pellucida, a visible germinal vesicle and defined nucleolus were considered morphologically normal. Oocytes not meeting these criteria were deemed abnormal. After 12 days (i)

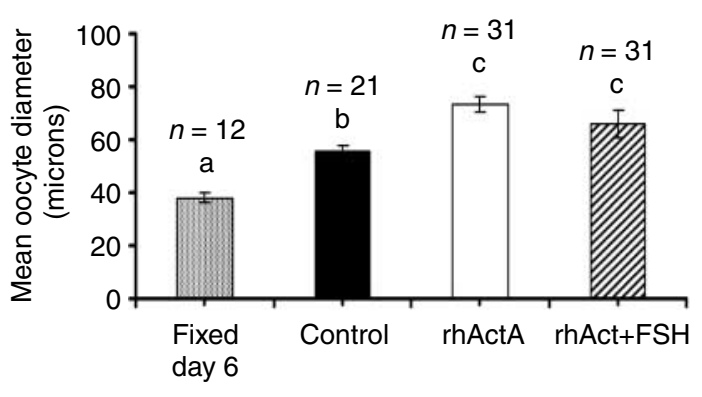

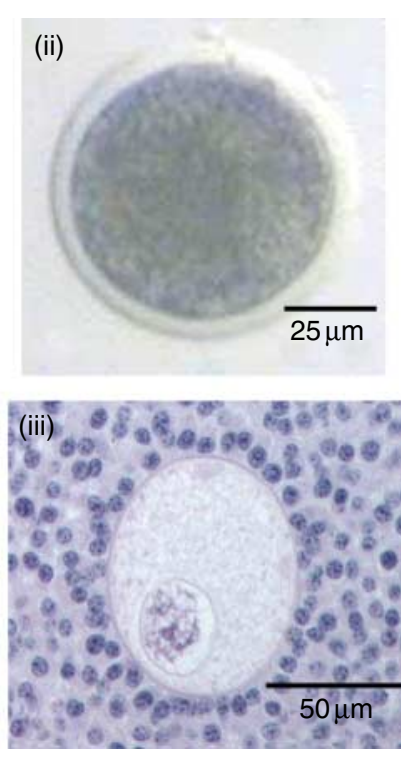

Figure 3 Effect of rhAct A and FSH on oocyte growth and morphology over 12 days in vitro. (i) Values are mean oocyte diameters \pm s.E.M.; $\mathrm{a}, \mathrm{b}$ and $\mathrm{c}$ indicate differences between treatments. Mean oocyte diameters were significantly greater in the presence of $100 \mathrm{ng} / \mathrm{ml}$ rhAct A with or without $50 \mathrm{ng} / \mathrm{ml} \mathrm{FSH}$ compared with the diameters of oocytes cultured in control medium $(P<0.05)$ and with those of oocytes of follicles cultured in strips for 6 days only $(P<0.01)$. (ii) Morphologically normal oocyte grown in vitro in the presence of $100 \mathrm{ng} / \mathrm{ml}$ rhAct $A$ alone for 12 days; bar $=25 \mu \mathrm{m}$. (iii) Histological image of morphologically normal in vitro grown oocyte cultured in the presence of $100 \mathrm{ng} / \mathrm{ml} \mathrm{rhAct} \mathrm{A}$ and $50 \mathrm{ng} / \mathrm{ml}$ rhFSH for 12 days; $b a r=50 \mu \mathrm{m}$. 
In vitro day 12

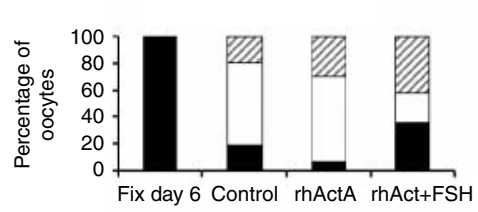

In vitro day 18

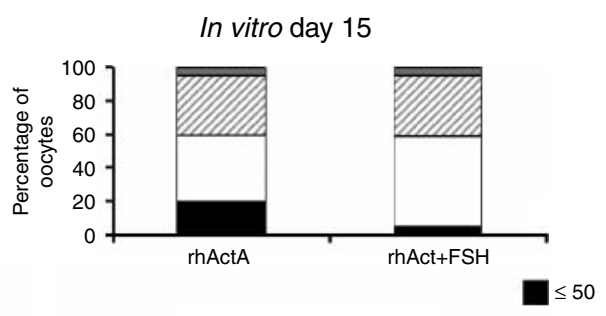

In vitro day 21

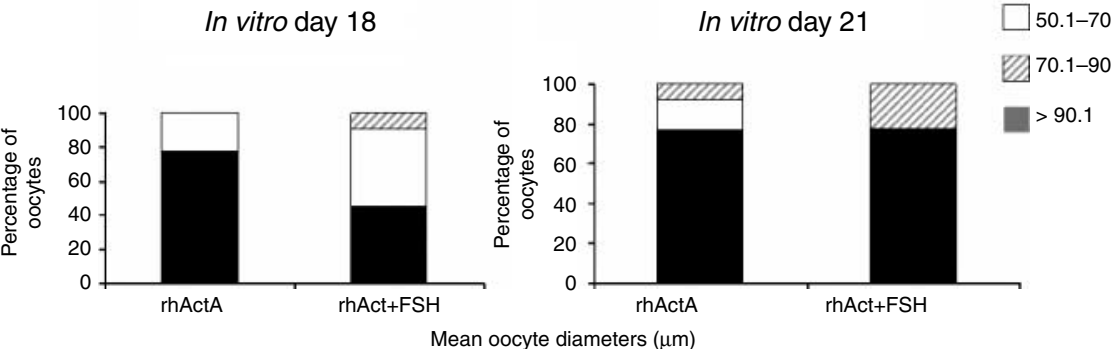

Figure 4 Distribution of oocytes by size at days 12, 15, 18 and 21. Maximum oocyte diameters were achieved after 15 days in vitro in the presence of $100 \mathrm{ng} / \mathrm{ml}$ rhAct $A$ or $100 \mathrm{ng} / \mathrm{ml}$ rhAct $A$ and $50 \mathrm{ng} / \mathrm{ml}$ rhFSH with some oocytes exceeding $100 \mu \mathrm{m}$ in diameter. By day 21, the percentage of oocytes of diameter $\leq 50 \mu \mathrm{m}$ had risen sharply in both groups indicating that culture conditions were suboptimal. in vitro, no significant difference in oocyte morphology was observed between the treatment groups (control $n=31$, activin $n=20$, and activin and FSH $n=20$ ), with $55-65 \%$ of all the oocytes cultured appearing morphologically normal. Oocyte-cumulus complexes were released from follicles cultured in $100 \mathrm{ng} / \mathrm{ml}$ rhAct A with or without $50 \mathrm{ng} / \mathrm{ml} \mathrm{rhFSH}$ on days 15 (activin $n=15$, and activin and $\mathrm{FSH} n=15$ ), 18 (activin $n=10$, and activin and FSH $n=8$ ) and 21 (activin $n=5$, and activin and $\mathrm{FSH} n=6$ ) of the total in vitro period, and the oocyte complexes were measured and assessed for the presence of adherent cumulus cells and an intact zona pellucida. Follicle degeneration increased steeply with time. At day $15,<5 \%$ of follicles cultured in the presence of activin alone and $<7 \%$ of those cultured in activin combined with $\mathrm{FSH}$ were degenerate, whereas by day 18 , this had risen to 32 and $39 \%$ respectively. By day 21 , almost $50 \%$ of the oocytes from both treatment groups were degenerate. As shown in Fig. 4, maximum oocyte diameters $(>90.1 \mu \mathrm{m})$ were achieved in follicles cultured for a total of 15 days in the presence of activin with or without FSH. A significantly greater proportion of oocytes had adherent cumulus cells when FSH was present in the culture medium $(P<0.05$; Fig. 5i) compared with oocytes cultured in activin alone at days 15 and 18; however, by day 21, nearly all the oocytes from both treatment groups were denuded on release (Fig. 5ii). Zona pellucidae were present and intact in all oocytes released from follicles on days 15, 18 and 21; however, by day 21, oocytes from both treatments appeared grossly misshapen (Fig. 5iii).

\section{Oestradiol secretion}

Media from follicles cultured individually in control medium (day $9, n=7$; day $12, n=7$ ), activin alone (day 9, $n=9$; day $12, n=9$ ) or activin with $\mathrm{FSH}$ (day 9, $n=7$; day $12, n=7)$ were analysed for oestradiol $\left(\mathrm{OE}_{2}\right)$ content by immunoenzyme assay. Significant $\mathrm{OE}_{2}$ secretion was observed in follicles cultured in activin alone $(P<0.05)$ compared with the other treatment groups; however, this effect was not sustained, and by day 12 , no significant difference was detected between treatments (Table 1).

\section{Discussion}

If mechanisms regulating germ cell development in nonrodent mammals are to be fully understood and competent oocytes are to be routinely produced in vitro, systems supporting the growth of large mammalian follicles from the earliest stages are a prerequisite. Although major milestones in bovine follicle growth have been realised in vitro, i.e. primordial follicle activation (Wandji et al. 1996, Fortune et al. 1998, Gigli et al. 2006, Yang \& Fortune 2006, 2007), preantral follicle growth (Wandji et al. 1996, Hulshof et al. 1997,
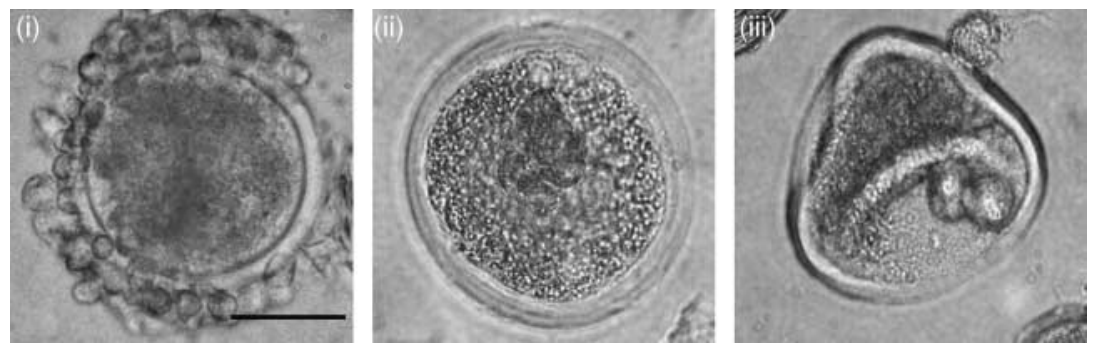

Figure 5 Oocyte morphology on aspiration after 15-21 days in culture. (i) Cumulus cells adhering to an oocyte released from a follicle cultured in the presence of activin and FSH for 15 days. (ii) Oocyte cultured in activin alone for 18 days; intact zona pellucida was visible but no adherent cumulus. (iii) Grossly misshapen oocyte released from a follicle cultured in $100 \mathrm{ng} / \mathrm{ml} \mathrm{rhAct} \mathrm{A}$ and $50 \mathrm{ng} / \mathrm{ml} \mathrm{rhFSH}$ for 21 days. 
Table 1 Oestradiol secretion in bovine follicles activated and grown in vitro.

\begin{tabular}{llc}
\hline & \multicolumn{2}{c}{ Mean oestradiol secretion $(\mathrm{pg} / \mathrm{ml})$} \\
\cline { 2 - 3 } & \multicolumn{1}{c}{ Day 9} & Day 12 \\
\hline Control & 28.45 & 32.61 \\
$100 \mathrm{ng} / \mathrm{ml} \mathrm{rhAct}$ & $41.31^{*}$ & 35.28 \\
$100 \mathrm{ng} / \mathrm{ml} \mathrm{rhAct}$ & 30.78 & 33.33 \\
$\mathrm{~A}+50 \mathrm{ng} / \mathrm{ml} \mathrm{rFSH}$ & & \\
\hline
\end{tabular}

*Denotes a significant difference between treatment groups at day 9 $(P<0.05)$.

Katska \& Ryńska 1998, Gutierrez et al. 2000, Saha et al. 2000, Thomas et al. 2001, 2007), oocyte-cumulus cell complex development (Ralph et al. 1995, Hirao et al. 2004), and oocyte maturation and fertilisation (Hirao et al. 2004), gaps still exist and a complete system capable of supporting the development of immature follicles through to oocyte competency is yet to be defined. It is not known exactly how long it takes for primordial follicles to reach the secondary stage in vivo; however, previous studies have observed a significant reduction in the primordial follicle population with a concomitant increase in the later stages of development in bovine cortical strips grown over 7 (Wandji et al. 1996, Gigli et al. 2006), 10 (Yang \& Fortune 2006, 2007) and 20 days (Fortune et al. 1998) in vitro, with primordial activation being observed as early as the second day of culture (Fortune et al. 1998). In this study, the mean diameter of follicles dissected from cortical fragments cultured for 6 days was $111 \pm 1.46 \mu \mathrm{m}$, considerably larger than $40 \mu \mathrm{m}$, the limit for exclusion from the experiment and smaller than the minimum diameter required for antral formation (Webb et al. 1999), indicating that secondary follicles that were present entered the growth phase in vitro from the quiescent pool, and that subsequent antral cavity formation occurred in vitro. This was confirmed by histological analysis as no secondary or antral follicles were observed in freshly fixed cortical fragments.

In this study, activin with or without FSH promoted follicle growth up to 18 days in vitro, and the formation of antral cavities in cultured secondary follicles was observed after 12 days. This demonstrates a markedly enhanced rate of development, as it is estimated that in vivo bovine primordial follicles take several months to reach the antral stage (Lussier et al. 1987, Gosden et al. 1994). Previous studies have achieved antral cavity formation after 7 and 10 days in vitro (Gutierrez et al. 2000, Itoh et al. 2002); however, both studies cultured larger preantral follicles $(166 \pm 2.15 \mu \mathrm{m})$. Activin and activin with $\mathrm{FSH}$ promoted follicle growth with follicle diameters increasing from 111 up to $200 \mu \mathrm{m}$ (activin alone) and $247 \mu \mathrm{m}$ (with FSH) with concomitant increase in oocyte diameters from $39 \mu \mathrm{m}$ to a maximum of $107 \mu \mathrm{m}$ over 15 days in vitro. Normal oocyte morphology was maintained in the presence of activin with or without $\mathrm{FSH}$; however, their competency is yet to be tested. Hirao et al. (2004) successfully cultured, matured and fertilised bovine oocyte-cumulus complexes in vitro with a mean oocyte diameter of $95 \mu \mathrm{m}$ on aspiration (Hirao et al. 2004). In this study, the largest oocytes were observed on day 15; moreover, in the presence of $100 \mathrm{ng} / \mathrm{ml}$ rhAct $A$ and $50 \mathrm{ng} / \mathrm{ml} \mathrm{rhFSH}$, oocytes retained adherent cumulus cells until day 18 , indicating that a close association between the germ and somatic cells was being maintained by culture conditions; however, extending the culture to 21 days resulted in oocyte degeneration. It is well established that maintenance of bidirectional communication between the oocyte and its surrounding somatic cells is vital to the production of a healthy oocyte (Albertini et al. 2001, Eppig 2001). Our results support the idea that to facilitate complete oocyte development in vitro, an additional culture step would need to be introduced to support the development of oocytes outwith the large antral follicle (Telfer \& McLaughlin 2007).

Follicles supplemented with $100 \mathrm{ng} / \mathrm{ml}$ rhAct A alone secreted significant $\mathrm{OE}_{2}$, which together with antral formation is indicative of follicle differentiation. Increased $\mathrm{OE}_{2}$ peaked at day 9 , and was not maintained throughout the culture period; however, the reduced steroidogenesis observed at day 12 did not have a deleterious effect on oocyte growth or morphology.

In summary, this study demonstrates the potential of secondary bovine follicles derived from primordial follicles activated in vitro to support continued oocyte development within isolated follicles. The presence of activin and FSH enhanced follicle and oocyte growth in vitro, with some follicles containing oocytes with diameters $>100 \mu \mathrm{m}$ after a 15 -day culture period. These results provide another encouraging step towards the realisation of complete in vitro growth of large mammalian oocytes.

\section{Materials and Methods}

\section{Tissue preparation and fragment culture}

Bovine ovaries from freshly killed heifers were transported from the local abattoir at $33-38{ }^{\circ} \mathrm{C}$ in HEPES-buffered M199 media (Invitrogen Ltd) supplemented with amphotericin B $(2.5 \mu \mathrm{g} / \mathrm{ml}$; Invitrogen Ltd), pyruvic acid $(25 \mu \mathrm{g} / \mathrm{ml})$, penicillin $\mathrm{G}(75 \mu \mathrm{g} / \mathrm{ml})$ and streptomycin $(50 \mu \mathrm{g} / \mathrm{ml}$; all chemicals obtained from Sigma Chemicals). Under laminar flow conditions, ovaries were rinsed in $70 \%$ alcohol, and fine cortical strips were removed using a scalpel. The strips were placed in a dissection medium (Leibovitz medium, Invitrogen Ltd) supplemented with sodium pyruvate $(2 \mathrm{mM})$, glutamine $(2 \mathrm{mM}$; both obtained from Invitrogen Ltd), BSA (Fraction $\mathrm{V}, 3 \mathrm{mg} / \mathrm{ml}$ ), penicillin $\mathrm{G}$ $(75 \mu \mathrm{g} / \mathrm{ml})$ and streptomycin $(50 \mu \mathrm{g} / \mathrm{ml}$; Sigma Chemicals $))$. Under light microscopy, any damaged, haemorrhaged or excess stromal tissue was excised, allowing the pieces to flatten and enhancing microscopic visualisation. The flat tissue pieces were dissected into fragments of between 0.5 and 
$1 \mathrm{~mm}^{2}$, and re-examined under light microscopy, and all visible follicles were measured. Any follicle of mean diameter $>40 \mu \mathrm{m}$ was excised from the tissue fragments to ensure that the presumptive population of follicles was unilaminar, i.e. primordial or transitory. Seven replicate cultures were established with 12-33 cortical fragments in each. The fragments were cultured individually in 24-well cell culture plates (Corning B.V. Life Sciences Europe, Amsterdam, The Netherlands) containing McCoy's 5a medium with bicarbonate supplemented with HEPES (20 mM; Invitrogen Ltd), glutamine (3 mM; Invitrogen Ltd), BSA (Fraction $\mathrm{V} 0.1 \%$ ), penicillin $\mathrm{G}$ $(0.1 \mathrm{mg} / \mathrm{ml})$, streptomycin $(0.1 \mathrm{mg} / \mathrm{ml})$, transferrin $(2.5 \mu \mathrm{g} / \mathrm{ml})$, selenium $(4 \mathrm{ng} / \mathrm{ml})$, insulin $(10 \mathrm{ng} / \mathrm{ml})$ and ascorbic acid $(50 \mu \mathrm{g} / \mathrm{ml}$; all obtained from Sigma Chemicals). Fragments were cultured for 6 days at $37^{\circ} \mathrm{C}$ in humidified air with $5 \%$ $\mathrm{CO}_{2}$, with half the media being removed and replaced every second day. A number of cortical fragments were randomly selected, and fixed on each day a culture was established (day 0) to allow comparison between cultured and in vivo follicular parameters.

\section{Follicle isolation and culture}

After 6 days, a number of cortical fragments were removed from each culture and fixed in Bouin's solution prior to secondary follicle dissection to allow comparison of follicle growth between day 0 and 6 (total $n=10$ ). The remaining cortical fragments $(n=233)$ were transferred to pre-warmed Leibovitz dissection medium supplemented as described earlier, and preantral follicles $(111 \pm 1.46 \mu \mathrm{m})$ were mechanically dissected with 25-gauge needles, and those with an intact basement membrane and no antral cavity were selected for culture. A total of 170 follicles were dissected, 12 follicles were fixed immediately as day 6 follicle controls, and 158 follicles were randomly assigned to treatment groups. Selected follicles were individually placed in 96-well V-bottomed culture plates (Corning Costar Europe, Badhoevedorp, The Netherlands) in $150 \mu \mathrm{l}$ of the culture medium. For the control group $(n=31)$, follicles were cultured in McCoy's 5a medium supplemented as described earlier. For the treatment groups, follicles were cultured in McCoy's 5a medium as described before with either $100 \mathrm{ng} / \mathrm{ml}$ rhAct A (R\&D Systems, Abingdon, UK; $n=70$ ) or $100 \mathrm{ng} / \mathrm{ml}$ rhAct $A$ in combination with $50 \mathrm{ng} / \mathrm{ml}$ rhFSH (Sigma Chemicals; $n=57$ ). The follicles were cultured individually for a maximum of 15 days at $37^{\circ} \mathrm{C}$ in humidified air with $5 \% \mathrm{CO}_{2}$, and on every third day, half the culture medium was removed and replaced concomitant with follicle diameter measurement using a dissecting microscope with a crossed micrometer. Upon microscopic inspection, any damaged or degenerate follicles were excluded from the study. The prevalence of follicle deterioration was not significantly different between the treatment groups.

\section{Assessment of histology}

A total of 12 fragments of fresh cortical tissue and ten fragments of tissue cultured for 6 days were fixed for $24 \mathrm{~h}$ in Bouin's solution and processed for histological inspection as described below. The developmental stage of the follicles that were present in the tissue was assessed by light microscopy, and the proportions of quiescent and growing follicles were compared between the groups. After a total of 12 days in vitro ( 6 days within cortical fragments and 6 days in individual follicle culture), 20 follicles each from both activinsupplemented treatment groups and all control-cultured follicles $(n=30)$ were fixed in Bouin's solution for $24 \mathrm{~h}$, and were then dehydrated in an eosin/alcohol solution in increasing concentrations (70, 90 and 100\%). Following dehydration, the follicles were immersed in cedarwood oil (BDH Laboratory Supplies, Poole, UK) for $24 \mathrm{~h}$ and were then placed in toluene (Fisher Scientific UK Ltd, Loughborough, UK) for $30 \mathrm{~min}$ to remove all traces of the oil. The follicles were then embedded in paraffin wax at $60{ }^{\circ} \mathrm{C}$ for $4 \mathrm{~h}$, with the wax being renewed every hour to ensure complete clearance of all the toluene. Six-micrometre-thick samples were sectioned, mounted on gelatine-coated slides and left to dry overnight prior to staining with haematoxylin and eosin. Using a light microscope with a crossed micrometer, sections of follicles containing the nucleolus were assessed, and the following parameters were evaluated: follicle and oocyte diameter, antral cavity formation and oocyte integrity. In total, 1-2 follicles from each activin-treated group cultured beyond a total of 12 days were fixed and processed as described above; the remaining follicles from these groups cultured for more than 12 days were assessed as detailed below.

\section{Assessment of oocyte-cumulus complexes}

A number of follicles cultured in $100 \mathrm{ng} / \mathrm{ml}$ rhAct $A$ with $(n=35)$ or without $(n=45) 50 \mathrm{ng} / \mathrm{ml} \mathrm{rhFSH}$ remained in vitro for a maximum total period of 21 days. Following 15 , 18 and 21 days in vitro, a number of follicles from each treatment group were removed to preheated Leibovitz dissection media supplemented as described earlier, and were gently opened using 25-gauge needles. Using a light microscope with a crossed micrometer, the released oocyte complexes were inspected, and oocyte diameter, zona pellucida integrity, cumulus cell adherence and oocyte morphology were evaluated.

\section{Measurement of $\mathrm{OE}_{2}$ by enzyme immunoassay}

To evaluate follicular steroidogenesis in vitro, concentrations of $\mathrm{OE}_{2}$ in reserved culture media were measured against standard dilutions using $\mathrm{OE}_{2}$ ELISA kit (DRG Instruments, $\mathrm{GmbH}$, Marburg, Germany). Media removed from follicles cultured in control $(n=7)$ or in the presence of $100 \mathrm{ng} / \mathrm{ml} \mathrm{rhAct} \mathrm{A} \mathrm{with}$ $(n=7)$ or without $(n=9) 50 \mathrm{ng} / \mathrm{ml} \mathrm{rhFSH}$ on days 9 and 12 of the total in vitro period were analysed. As per the immunoassay kit instructions (DRG Instruments), reserved media were diluted with freshly prepared culture medium (1 in 10), placed in microtiter wells coated with polyclonal (rabbit) antibody raised against the $\mathrm{OE}_{2}$ antigenic site, mixed with $\mathrm{OE}_{2}-\mathrm{HRP}$ conjugate and incubated for $120 \mathrm{~min}$. After incubation, the unbound conjugate was washed off, and a substrate solution of tetramethylbenzidine was added to allow development of colour. After $15 \mathrm{~min}$, the reaction was stopped using dilute sulphuric acid, the wells were washed, and the absorbance of 
each well at $450 \pm 10 \mathrm{~nm}$ was measured using a microtiter plate reader. The absorbencies were converted to $\mathrm{OE}_{2}$ concentrations using Sigma Plot Version 9, with four parametric logistic functions (Systat Software Inc., Hounslow, UK) and $\mathrm{OE}_{2}$ sensitivity of $25 \mathrm{pg} / \mathrm{ml}$. Specificity of the assay was as follows: $\mathrm{OE}_{2} 100 \%$, oestriol $0.055 \%$ and oestrone $0.2 \%$. The inter- and intra-coefficients of variation were 6.81 and $7.25 \%$ respectively.

\section{Statistical analyses}

Inter- and intra-treatment differences were compared by measuring mean follicle diameters, mean oocyte diameters and $\mathrm{OE}_{2}$ production on every third day of culture using a oneway ANOVA with subsequent $t$-tests. The proportions of quiescent and primary follicles and normal oocyte morphology were compared using $\chi^{2}$ analysis. The proportions of antral cavity and zona pellucida formation and cumulus cell adherence were compared using Fisher's exact test.

\section{Declaration of interest}

The authors declare that there is no conflict of interest that could be perceived as prejudicing the impartiality of the research reported.

\section{Funding}

Funding for this study was provided for M McLaughlin by a joint CASE PhD studentship between the Biotechnology and Biological Sciences Research Council and Trans Ova Genetics, lowa, USA.

\section{Acknowledgements}

The authors wish to thank Mr John Binnie for excellent technical assistance.

\section{References}

Abir R, Franks S, Mobberley MA, Moore PA, Margara RA \& Winston RM 1997 Mechanical isolation and in vitro growth of preantral and small antral human follicles. Fertility and Sterility 68 682-688.

Albertini DF, Combelles CM, Benecchi E \& Carabatsos MJ 2001 Cellular basis for paracrine regulation of ovarian follicle development. Reproduction 121 647-653.

Braw-Tal R \& Yossefi S 1997 Studies in vivo and in vitro on the initiation of follicle growth in the bovine ovary. Journal of Reproduction and Fertility 109 165-171.

Eppig JJ 2001 Oocyte control of ovarian follicular development and function in mammals. Reproduction 122 829-838.

Eppig JJ \& O'Brien MJ 1996 Development in vitro of mouse oocytes from primordial follicles. Biology of Reproduction 54 197-207.

Eppig JJ \& Schroeder A 1989 Capacity of mouse oocytes from preantral follicles to undergo embryogenesis and development to live young after growth, maturation, and fertilization in vitro. Biology of Reproduction 41 268-276.

Fabbri R, Pasquinelli G, Montanaro L, Mozzanega B, Magnani V, Tamburini F, Venturoli S \& Keane D 2007 Healthy early preantral follicle can be obtained in a culture of frozen-thawed human ovarian tissue of 32 weeks. Ultrastructural Pathology 31 257-262.

Fortune JE, Kito S, Wandji SA \& Srsen V 1998 Activation of bovine and baboon primordial follicles in vitro. Theriogenology 49 441-449.
Gigli I, Byrd DD \& Fortune JE 2006 Effects of oxygen tension and supplements to the culture medium on activation and development of bovine follicles in vitro. Theriogenology 66 344-353.

Gosden RG \& Telfer EE 1987 Scaling of follicular sizes in mammalian ovaries. Journal of Zoology 211 157-168.

Gosden RG, Baird DT, Wade J \& Webb R 1994 Restoration of fertility to oophorectomized sheep by ovarian autografts stored at $-196^{\circ} \mathrm{C}$. Human Reproduction 9 597-603.

Gutierrez CG, Ralph JH, Telfer EE, Wilmut I \& Webb R 2000 Growth and antrum formation of bovine preantral follicles in long-term culture in vitro. Biology of Reproduction 62 1322-1328.

Hirao Y, Itoh T, Shimizu M, Iga K, Aoyagi K, Kobayashi M, Kacchi M, Hoshi H \& Takenouchi N 2004 In vitro growth and development of bovine oocyte-granulosa cell complexes on the flat substratum: effects of high polyvinylpyrrolidone concentration in culture medium. Biology of Reproduction 70 83-91.

Hovatta O, Silye R, Abir R, Krausz T \& Winston RM 1997 Extracellular matrix improves survival of both stored and fresh human primordial and primary ovarian follicles in long-term culture. Human Reproduction 12 1032-1036.

Hovatta O, Wright C, Krausz T, Hardy K \& Winston RM 1999 Human primordial, primary and secondary ovarian follicles in long-term culture: effect of partial isolation. Human Reproduction 14 2519-2524.

Hulshof SC, Figueiredo JR, Beckers JF, Bevers MM, Vanderstichele H \& van den Hurk R 1997 Bovine preantral follicles and activin: immunohistochemistry for activin and activin receptor and the effect of bovine activin A in vitro. Theriogenology 48 133-142.

Itoh T, Kacchi M, Abe H, Sendai Y \& Hoshi H 2002 Growth, antrum formation, and estradiol production of bovine preantral follicles cultured in a serum-free medium. Biology of Reproduction 67 1099-1105.

Katska L \& Ryńska B 1998 The isolation and in vitro culture of bovine preantral and early antral follicles of different size classes. Theriogenology 15 213-222.

Liu X, Andoh K, Yokota H, Kobayashi J, Abe Y, Yamada K, Mizunuma H \& Ibuki Y 1998 Effects of growth hormone, activin, and follistatin on the development of preantral follicle from immature female mice. Endocrinology 139 2342-2347.

Louhio H, Hovatta O, Sjöberg J \& Tuuri T 2000 The effects of insulin, and insulin-like growth factors I and II on human ovarian follicles in longterm culture. Molecular Human Reproduction 6 694-698.

Lussier JG, Matton P \& Dufour JJ 1987 Growth rates of follicles in the ovary of the cow. Journal of Reproduction and Fertility 81 301-307.

McNatty KP, Heath DA, Hudson N \& Clarke IJ 1990 Effect of long-term hypophysectomy on ovarian follicle populations and gonadotrophininduced adenosine cyclic $3^{\prime}, 5^{\prime}$-monophosphate output by follicles from Booroola ewes with and without the F gene. Journal of Reproduction and Fertility 90 515-522.

Oktay K, Nugent D, Newton H, Salha O, Chatterjee P \& Gosden RG 1997 Isolation and characterization of primordial follicles from fresh and cryopreserved human ovarian tissue. Fertility and Sterility 67 481-486.

Oktay K, Newton H, Mullan J \& Gosden RG 1998 Development of human primordial follicles to antral stages in SCID/hpg mice stimulated with follicle stimulating hormone. Human Reproduction 13 1133-1138.

Peters H, Byskov AG, Lintern-Moore S \& Faber M 1973 Proceedings: follicle growth initiation in the immature mouse ovary: extraovarian or intraovarian control? Journal of Reproduction and Fertility 35 619-620.

Ralph JH, Telfer EE \& Wilmut I 1995 In vitro growth of bovine preantral follicles and the influence of FSH on follicular and oocyte diameters. Journal of Reproduction and Fertility Abstract Series $\mathbf{1 5}$ abstract 6.

Saha S, Shimizu M, Geshi M \& Izaike Y 2000 In vitro culture of bovine preantral follicles. Animal Reproduction Science 63 27-39.

Segino M, Ikeda M, Hirahara F \& Sato K 2005 In vitro follicular development of cryopreserved mouse ovarian tissue. Reproduction 130 $187-192$.

Silva JR, Tharasanit T, Taverne MA, van der Weijden GC, Santos RR, Figueiredo JR \& van den Hurk R 2006 The activin-follistatin system and in vitro early follicle development in goats. Journal of Endocrinology $\mathbf{1 8 9}$ 113-125.

Spears N, Boland NI, Murray AA \& Gosden RG 1994 Mouse oocytes derived from in vitro grown primary ovarian follicles are fertile. Human Reproduction 9 527-532. 
Telfer EE 1998 In vitro models for oocyte development. Theriogenology 49 451-460.

Telfer EE \& McLaughlin M 2007 Natural history of the mammalian oocyte. Reproductive Biomedicine Online 15 288-295.

Telfer EE, Binnie JP \& Jordan LB 1998 Effect of follicle size on the onset of apoptotic cell death in cultured bovine ovarian follicles. Theriogenology 49357.

Telfer EE, McLaughlin M, Ding C \& Thong KJ 2008 A two-step serum-free culture system supports development of human oocytes from primordial follicles in the presence of activin. Human Reproduction 23 1151-1158.

Thomas FH, Leask R, Srsen V, Riley SC, Spears N \& Telfer EE 2001 Effect of ascorbic acid on health and morphology of bovine preantral follicles during long-term culture. Reproduction 122 487-495.

Thomas FH, Armstrong DG \& Telfer EE 2003 Activin promotes oocyte development in ovine preantral follicles in vitro. Reproductive Biology and Endocrinology 176.

Thomas FH, Campbell BK, Armstrong DG \& Telfer EE 2007 Effects of IGF-I bioavailability on bovine preantral follicular development in vitro. Reproduction 133 1121-1128.

Wandji SA, Srsen V, Voss AK, Eppig JJ \& Fortune JE 1996 Initiation in vitro of growth of bovine primordial follicles. Biology of Reproduction $\mathbf{5 5}$ 942-948.

Wandji SA, Srsen V, Nathanielsz PW, Eppig JJ \& Fortune JE 1997 Initiation of growth of baboon primordial follicles in vitro. Human Reproduction 12 1993-2001.

Webb R, Gosden RG, Telfer EE \& Moor RM 1999 Factors affecting folliculogenesis in ruminants. Animal Science 68 257-284.
Wright CS, Hovatta O, Margara R, Trew G, Winston RM, Franks S \& Hardy K 1999 Effects of follicle-stimulating hormone and serum substitution on the in vitro growth of human ovarian follicles. Human Reproduction 14 1555-1562.

Xiao S, Robertson DM \& Findlay JK 1992 Effects of activin and follicle-stimulating hormone (FSH)-suppressing protein/follistatin on FSH receptors and differentiation of cultured rat granulosa cells. Endocrinology 131 1009-1016.

Yang MY \& Fortune JE 2006 Testosterone stimulates the primary to secondary follicle transition in bovine follicles in vitro. Biology of Reproduction 75 924-932.

Yang MY \& Fortune JE 2007 Vascular endothelial growth factor stimulates the primary to secondary follicle transition in bovine follicles in vitro. Molecular Reproduction and Development 74 1095-1104.

Zhang P, Louhio H, Tuuri T, Sjöberg J, Hreinsson J, Telfer EE \& Hovatta $\mathbf{O}$ 2004 In vitro effect of cyclic adenosine $3^{\prime}, 5^{\prime}$-monophosphate (cAMP) on early human ovarian follicles. Journal of Assisted Reproduction and Genetics 21 301-306.

Zhao J, Taverne MA, van der Weijden GC, Bevers MM \& van den Hurk $R$ 2001 Effect of activin A on in vitro development of rat preantral follicles and localization of activin A and activin receptor II. Biology of Reproduction 65 967-977.

Received 15 January 2010

First decision 23 February 2010

Accepted 4 March 2010 